\title{
The Doctrine of Constructive Trusts as Laid Down in Curdy v. Berton
}

\begin{abstract}
A $\mathrm{N}$ odd, interesting case is Curdy v. Berton. ${ }^{1}$ Although cited several times by the California Supreme Court, no comment has ever been made on the singular logic of the decision.

The facts in the case, in brief, are as follows: The testatrix executed a will, by which she gave to one Berton certain money which, the will provided, was to be distributed by Berton "according to the private instructions I give him." It appeared in evidence that Berton was present when the will was made, and that at the time of its execution the testatrix verbally instructed him to distribute the money left him to certain relatives other than the plaintiff in the action. It further appeared that Berton at least impliedly agreed to accept the trust. After the death of the testatrix, Berton faithfully distributed the property in accordance with the instructions given him. Thereafter, action was brought by the plaintiff, a brother of the deceased and one of her heirs at law, to have it decreed that Berton took the legal title to the property left him in trust for the heirs of the deceased, for an accounting, and for the payment to plaintiff of his proportionate share of the money. The court gave judgment for defendant and plaintiff appealed. The contention of the appellant was, in brief, that as the statute law of this state requires a will to be in writing, therefore "where a testator devises property in trust to be applied to such uses as the testator has verbally specified to the devisee, the trust attempted to be created by parol fails, and the devisee takes the property in trust for the heirs of the testator." The contention of the respondent on the other hand, as stated by the court, was that "independent of the statute of wills, where a testator bequeaths property in trust to a legatee, without specifying in the will the purposes of the trust, and at the same time communicates those purposes to the legatee orally, or by any attested writings, and the legatee, either expressly or by silent acquiescence, promises to perform the trust, and the trust itself is not unlawful, there a court of equity will raise a constructive trust in favor of the beneficiaries intended by the testator, and will charge the legatee as a constructive trustee for them, upon the ground that the legatee will not be countenanced in perpetrating a fraud, by
\end{abstract}

I (1889) 79 Cal. 420, 21 Pac, 858, 5 L. R. A. 189. 
encouraging the testator to make a bequest which would not otherwise have been made, and then refusing to execute his promise."2

In brief, the question was assumed to be whether there was a resulting trust for the heirs or a constructive trust for the beneficiaries.

The court upheld the respondent's contention and affirmed the judgment. But wherein lay the fraud? Berton did not refuse to execute his promise. On the contrary, he carried it out in perfect good faith.

It will be borne in mind that, as was held in Cooney v. Glynn :8

"It is the violation of the parol promise which constitutes the fraud upon which the trust arises. If made in good faith, and if it is of a continuing nature, the performance of it for a time does not prevent a trust from arising when it is broken and repudiated."

Likewise in the case of Taylor v. Morris the court said:

"The statute of frauds is never permitted to become a shield for fraud, and fraud at once arises upon the repudiation by the trustee of any trust, even if that trust rests in parol."

How then did the court reach its conclusion that a constructive trust existed?

In its opinion, the court quoted at length from the case of Will of O'Haras which, our court said, contained "a lucid statement of the principles which apply to the case at bar."

In the New York case, the facts were that a testatrix had left the bulk of her estate to three legatees without suggesting in her will that the legacy was in trust. It appeared upon the trial that, contemporaneously with the execution of the will, a letter of instructions addressed to them, and dictating the purposes of the legacy, had been given to them. From this letter it appeared that the legacy was for certain charitable purposes stated therein.

Although intending to carry out the wishes of the testatrix, the legatees stood upon their rights under the terms of the will, denied that they had accepted any trust, or that any could be proven by extrinsic matter lying outside the will, and insisted that the property was theirs absolutely. Therefore, said our supreme court: "The question thus presented was, in substance, the one presented here." This overlooks the fact that in the O'Hara case it did not appear on the face of the will that the testatrix intended the legatees to

2 Italics here and elsewhere are ours unless otherwise indicated.

3 (1910) 157 Cal. 583, 587, 108 Pac. 506.

4 (1912) 163 Cal. 717, 127 Pac. 66.

5 (1884) 95 N. Y. 403,47 Am. Rep. 53. 
hold the property in trust. The court thereupon quoted from the O'Hara case as follows: "If, therefore, in her letter of instructions, the testatrix had named some certain and definite beneficiary capable of taking the provision intended, the law would fasten upon the legatee a trust for such beneficiary, and enforce it, if needed, on the ground of fraud. Equity acts, in such case, not because of a trust declared by the testator, but because of the fraud of the legatee. For him not to carry out the promise by which alone he procured the devise and bequest is to perpetrate a fraud upon the devisor, which equity will not endure."

Our court concluded that the doctrine of the O'Hara case, supported as it was by certain other cases cited, led to the conclusion that the judgment rendered by the lower court was correct.

The quotation from the O'Hara case, together with additional portions of the opinion, make it clear that the basis of the holding of our court was that a constructive trust based upon fraud existed. But, as has been pointed out, fraud, in the sense in which the term is used in this state, was not present. On the contrary, the defendant had carried out the trust imposed on him in good faith. Moreover, the quotations from the O'Hara case are entirely misleading. The court in that case expressly stated that there was no claim of a repudiation by the trustees of their promise, and that no beneficiary claimed any such violation of duty, or even as threatened or intended.

The court in the O'Hara case then proceeded as follows:

"But it may happen, as it does happen here, that all of the charitable uses enjoined are for the benefit of those incapable of taking, or of a character in direct violation of the law of the state. What then becomes the duty of a court of equity? A fraud remains, except that it takes on graver proportions, and becomes more certain and inevitable. The agreement which induced the absolute devise, and the fraud of a beneficial holding secured by a contrary promise, still confronts us. And what is worse, it does not need that the absolute legatees repudiate their promise, for if ever so honorably willing to perform it, they cannot do so without setting at defiance and secretly evading the law and general policy of the state. The alternative is plain, and offers no chance of escape. If the legatees repudiate their obligations, that is a fraud upon the dead woman, who acted upon the faith of their promise. If they are willing to perform they cannot perform, except by a fraud upon the law to which they and the testatrix are equally parties."

The New York court then considered the character of the charitable uses upon which the legatees agreed to hold the residuary estate, and concluded that the plan violated the statute against perpetuities, both as to the real and personal estate. The conclusion of the court 
was that "Any devise or bequest of this character is dangerous and indefensible. It exposes testators to the suggestion of unnecessary difficulkies as inducements to the artifice of an absolute devise concealing an illegal trust. It exposes the devisee to temptation and, even when he acts honestly, to severe and unrelenting criticism. It subserves no good or useful purpose. If we sustain it we admit that any statute may be thus evaded, and that equity cannot redress the wrong."

That the O'Hara case was decided on the latter ground, and not on the ground of fraud against the testatrix, was recognized in the later California case of Lauricella v. Lauricella. ${ }^{3}$

It will thus be seen that the O'Hara case was far from being an authority for the conclusion reached by our court in Curdy v. Berton. That it did not justify the conclusion reached is further made clear by the New York Court of Appeals in the comparatively recent case of Reynolds $v$. Reynolds, ${ }^{7}$ in which the court pointed out that decision in Curdy v. Berton was "based on an erroneous application of the O'Hara case."

In that case, as in the Curdy case, a trust appeared on the face of the will, but for purposes which did not appear, the testator reciting that the executor to whom the property was left in trust had been inforned of the purposes which the testator had in view. It was held by the court that the trust failed and that the next of kin took the property. The O'Hara case was distingnished on the ground that the facts there were different, in that the will did not purport to create a trust. The court said that "the total failure to designate the beneficiaries of the trust in the will makes it to that extent an unwritten will ineffectual for that purpose." Moreover, the court quotes from and follows the Massachusetts case of Olliffe v. Wells. ${ }^{8}$ That case had been relied upon by the appellant in the case of Curdy v. Berton, but the court in commenting on it said that "the weight of authority and the better reason are the other way."

In Curdy v. Berton, the court concludes by citing certain other authorities, and particularly certain English eases as laying down a rule under which the beneficiary intended by the testator rather than his heirs take the property, which rule it considered preferable to that enunciated by the Massachusetts Supreme Court.

Typical of those cases is In re Fleetwood. ${ }^{9}$ In this case, the

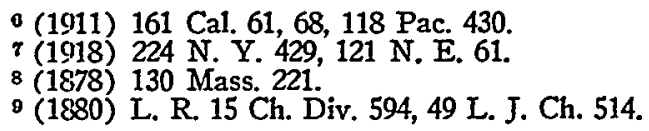


fact that the testatrix intended the legatee to hold the property in trust appeared upon the face of the will, but the beneficiaries were not there named. It was argued in that case, on behalf of the next of kin, that a distinction should be made between a case where the trust appears and a case where it does not appear on the face of the will. Also that:

"The Wills Act requires all wills to be in writing, and the Statute of Frauds requires all declarations of trusts to be in writing, and where a testator does not show upon the face of his will who is to take, the omission cannot be supplied by parol without violating those statutes, unless fraud for which those statutes are not to be used as instruments, is an ingredient in the case; and accordingly where parol evidence has been admitted, it has been in cases where the trustee against conscience endeavored to retain the property for his own benefit."

But Vice-Chancellor Hall held that no distinction could be made between a case where the trust appears upon the face of the will, and one where it did not so appear. He examined the authorities at length and concluded:

"In the present case the promise was the inducement to and created the gift. Can the court allow a trust to arise for the next of kin under a gift obtained under such circumstances as existed in this case, the creation of the trust and the intended gift being contemporaneous, and thus there not being any interval allowing of any resulting trust for the next of kin? The declaration of trust was incorporated with the intended creation of the trust. This question of personal fraud was urged in some of the cases I have above mentioned, which are authorities for sustaining the validity of the trusts. In Riordan v. Banon the Vice-Chancellor specifically examined and dealt with the question of personal fraud.

"My conclusion on this part of the case is that the court should and will execute the trusts intended to be reposed in the trustee Beaumont by the testatrix, if the trusts be established in evidence. I am of opinion that they are."10

In Riordan v. Banon, ${ }^{11}$ which Vice-Chancellor Hall cited, the court said:

"The testator, at least when his purpose is communicated to and accepted by the proposed legatee, makes the disposition to him on the faith of his carrying out his promise, and it would be a fraud in him to refuse to perform that promise. No doubt

10 That this broad rule has not been altogether approved even in England, see 29 Law Journal, 402. Also see Balfe v. Halfpenny (1904) 1 Ir. Rep. 485, 7 Ir. L. Rep. 832, in which it was said of Riordan v. Banon (1876) Ir. Rep. 10 Eq. 469, which was one of the cases cited with approval in Curdy v. Berton, that such cases "have not always been accepted without question."

11 Supra, n. 10. 
the fraud would be of a different kind if he could by means of it retain the benefit of the legacy for himself; but it appears that it would also be a fraud though the result would be to defeat the expressed intention for the benefit of the heir, next of kin, or residuary donees."

We may add that the latest word on the subject in England appears to be the decision in the case of In re Gardner, ${ }^{12}$ decided in 1920. In that case the trust did not appear upon the face of the will, as that document was construed by the court, but the case is instructive as indicating the reasoning upon which the English doctrine is based. The husband, to whom the property had been left in reliance upon his promise to carry out the wishes of the testatrix, died a few days after the death of the testatrix, and there was no question of repudiation or breach of trust upon his part. The intended beneficiary claimed the property, and this claim was contested by the next of kin. The court held that the beneficiary to whom the testatrix had intended the property should go, should prevail, saying:

"In accordance, therefore, with all the authorities it appears to me that in these circumstances the husband would not have been entitled to keep this fund had he lived. It would have been, as the cases say, a fraud on his part to do so. Equally would it be a fraud for those who claim under him as volunteers to do so. Accordingly, in my opinion, the appellants are entitled to succeed."

It will be observed that the doctrine of the English cases is in brief that if the legatee, expressly or impliedly, promises the testator to carry out the wishes of the latter in regard to the distribution of the estate left to him, a constructive trust is thereby impressed on the property, which will adhere to it regardless of the good or bad faith of the legatee.

But such is not the doctrine that exists, generally speaking, in this country. The California courts in particular seem committed to the contrary doctrine in the absence of a breach of the promise made, as has been seen from the California decisions cited above. Even a breach of a promise made to a grantor by whom real property is conveyed to a promisee in reliance upon the promise made by the latter to reconvey to the grantor or to convey to a third person, is not of itself sufficient to justify a decree that a constructive trust exists. Fraud, either actual or constructive, in another sense than that accorded to the term in England, must also be shown. It was well settled in this state at a comparatively early

12 [1920] 2 Ch. Div. 523, 1 Eq. R. 57. 
date that "the mere failure to fulfill a promise is not fraud." 13 However, in the case from which we quote, it was also held that a breach of a promise made constituted constructive fraud if a fiduciary relation existed between the parties. Such has ever since been the settled rule in this state. Moreover, for many years the courts of California held that such fiduciary relation must have existed prior to the making of the promise. In Taylor v. Morris, ${ }^{14}$ it was for the first time held that the trust relationship might be created contemporaneously with the acquisition of the property upon which it was sought to impress a trust. This was taking a very advanced step, and beyond it our courts have not gone.

Hence there appears to be no valid foundation for the decision of the court in Curdy v. Berton that a constructive trust existed.

Should the court have held as contended by the appellant that the legatees took the property under a resulting trust for the heirs? It will be recalled that the court rejected that argument, which was advanced by the appellant, and which was based upon the doctrine enunciated by the Massachusetts Supreme Court in Olliffe v. Wells. ${ }^{15}$ The Massachusetts court distinguished between a case where the attempted trust appears upon the face of the will, which was the situation in Curdy v. Berton, and a case where it did not so appear. Said that court:

"Where a trust not declared in the will is established by a court of chancery against the devisee, it is by reason of the obligation resting upon the conscience of the devisee, and not as a valid testamentary disposition by the deceased. Cullen v. Attorney General, L. R. 1 H. L. 190. Where the bequest is outright upon its face, the setting up of a trust, while it diminishes the right of the devisee, does not impair any right of the heirs or next of kin, in any aspect of the case; for if the trust were not set up, the whole property would go to the devisee by force of the devise; if the trust set up is a lawful one, it enures to the benefit of the cestuis que trust; and if the trust set up is unlawful, the heirs or next of kin take by way of resulting trust. Boson v. Statham, 1 Eden, 508; S. C. 1 Cox. Ch. 16. Russell v. Jackson, 10 Hare, 204. Wallgrave v. Tebbs, 2 K. \& J. 313. Where the bequest is declared upon its face to be upon such trusts as the testator has otherwise signified to the devisee, it is equally clear that the devisee takes no beneficial interest; and, as between him and the beneficiaries intended, there is as much ground for establishing the trust as if the bequest to him

18 Brison v. Brison (1888) 75 Cal. 525, 527, 17 Pac. 689; accord, Newman v. Smith (1888) 77 Cal. 22, 18 Pac. 791 ; Feeney v. Howard (1889) 79 Cal. 525, 21 Pac. 984.

14 Supra, n. 4.

15 Supra, n. 8. 
were absolute upon its face. But as between the devisee and the heirs or next of kin, the case stands differently. They are not excluded by the will itself. The will upon its face showing that the devisee takes the legal title only and not the beneficial interest, and the trust not being sufficiently defined by the will to take effect, the equitable interest goes, by way of resulting trust, to the heirs or next of kin, as property of the deceased, not disposed of by his will. Sears v. Hardy, 120 Mass. 524, 541,542 . They cannot be deprived of that equitable interest, which accrues to them directly from the deceased, by any conduct of the devisee; nor by any intention of the deceased, unless signified in those forms which the law makes essential to every testamentary disposition. A trust not sufficiently declared on the face of the will cannot therefore be set up by extrinsic evidence to defeat the rights of the heirs at law or next of kin."

Professor Pomeroy, in speaking of Olliffe v. Wells, said: "This distinction seems to be entirely unsupported by authority."18

On the other hand, the court in the case of Atwood v. Rhode Island Hospital \& Trust $\mathrm{Co}_{0}{ }^{17}$ decided many years after $\mathrm{Mr}$. Pomeroy had written, expressed itself as of the opinion that the decision in Olliffe v. Wells was "sound in principle and supported by the overwhelming weight of authority."

The court in the case of Olliffe $v$. Wells ${ }^{18}$ cited Lewin on Trusts as one of the authorities expressing the view that where the trust appeared upon the face of the will, it resulted to the heirs of the testator. Mr. Lewin in his treatise expressed this opinion as follows:

"Should the testator devise the estate in such language that the will passes the legal estate only to the devisee, and manifests an intention of not conferring the equitable, in short, stamps the devisee with the character of trustee, and yet does not define the particular trusts upon which he is to hold; in this case, no paper not duly attested (except of course papers existing at the date of the will, and incorporated by reference) will be admissible to prove what were the trusts intended. Nor will the devisee be allowed to retain the beneficial interest himself; but while the legal estate passes to him, the equitable will, according to the date and terms of the will, result to the testator's heir-at-law or general residuary devisee."19

Professor Costigan, following the argument of Professor Ames ${ }^{20}$ maintains that the doctrine of the Massachusetts court that a resulting trust exists for the heirs when the attempted trust appears upon the face of the will, is unsound. Says Professor Costigan:

163 Pomeroy, Equity Jurisprudence, 4 ed., 2410 (1918).

17 (1.921) 275 Fed. 513, citing numerous cases.

18 Supra, n. 8. (1910).

19 Lewin on Trusts, 8 ed., 59, 60 (1889); Jarman on Wills, 6 ed., 909-10

${ }^{20}$ Ames, Lectures on Legal History, 288-9 (1913). 
"That theory is erroneous, because it assumes that the testator dies possessed of two separate interests in the property, viz., a legal interest and an equitable, whereas he could have and did have only one. Our law of merger of estates and of other interests of itself makes that true. What happens on a devise expressly 'in trust,' but on trusts not expressed, is that on testator's death all his interest passes under the will, and then equity imposes a trust because of the clear expression of intention that the legatee or devisee should not keep beneficially. That trust is not an express trust in writing - the words 'in trust' or equivalent words in the will simply negative any presumption that the devisee is to take beneficially - and in so far as the devisee seeks to keep for himself it is in no sense express but is wholly constructive. Accordingly equity can and should select the cestui que trust for this constructive trust cy pres the testator's intentions and in harmony with the devisee's promise."21

This cestui is, of course, the person intended by the testator.

But in a state of facts such as was presented in Curdy v. Berton, Professor Costigan is likewise of the opinion that the beneficiary should recover, but for another reason. Of such a situation, he says :

"Where, however, the devisee does not try to keep the property devised, and is not indifferent, but instead seeks to carry out the testator's wishes, chancery does not have to enforce any trust whatever. It should not interfere with the carrying out of the express oral or otherwise unattested trust, because there is no express written trust in conflict with it to suggest such action, even if such an express written trust would justify such interference, and because there is no unjust enrichment to be rectified by the creation and enforcement of a constructive trust. The case where a legacy or devise is expressly 'in trust,' but the terms of the trust and the names of the intended beneficiaries are not found in the will, but were communicated by the testator to the legatee or devisee, should be decided exactly the same way as the case where the legacy or devise is absolute on its face and the same communication took place."22

But is this not glossing over the difficulty? Assume that under such a state of facts as existed in Curdy v. Berton, the legatee was planning in good faith to carry out the promise made by him to the testator. However, before he has done so, the heirs of the testator sue to have a trust in their favor decreed. The court to which the controversy is submitted must pass on the claim of the plaintiffs. Clearly the legatee does not take the property beneficially. Hence he must take it as trustee. We agree with Professor Costigan that

2128 Harvard L. Rev. 366, 384 (1915).

2228 Harvard L. Rev. 386 (1915). 
under the doctrine of constructive trusts as it exists in this country, he does not hold as a constructive trustee. Does it not then necessarily follow that he holds under a resulting trust? We may again agree with Professor Costigan (notwithstanding the holding of the Massachusetts court) that this does not follow from the fact that the equitable interest of the testator was not disposed of by him, and therefore passed to the heirs as an undisposed of interest in the property.

But does this exhaust all of the possibilities?

If it were not a will that was involved in Curdy v. Berton, it might properly be urged that there was a valid trust which could only be defeated by a plea by the trustee that the trust was not sufficiently proved by the terms of the will.

There is a line of cases holding that when property has been conveyed by a grantor to a grantee under an oral trust for a third person, the trust is merely voidable, and not void. Hence it has been held that although the grantee is entitled to plead the statute of frauds, he nevertheless may, if he desires, convey to the intended beneficiary, and mayr do so even after he has become bankrupt, and notwithstanding the objections of his creditors. This upon the ground that "while as against the grantee the cestui que trust has no rights which he can enforce, still if the grantee chooses to recognize his 'moral' obligation as it is called, his creditors cannot complain." ${ }^{23}$

Under this same principle that the trust is valid though voidable, it has been held in a recent case that a creditor of such trustee cannot attach property held by the latter under an oral trust for a debt of the trustee. ${ }^{24}$

So far as the validity of trusts inter vivos is concerned, it would seem that a distinction might at one time have been made on this point in California, between trusts involving real and those involving personal property. It has long been settled in this state that trusts in personal property may be created by parol. ${ }^{25}$

In the case of trusts in real property inter vivos, it was for a time uncertain whether they could be regarded as valid even in the absence of a plea of the statute of frauds. It was held in the case of Feeney v. Howard ${ }^{26}$ that the failure to comply with the statute of frauds rendered a contract coming within its provisions void. But it has since been held that the statute of frauds merely affects

${ }^{23}$ Bryant v. Klatt (1924) 2 F. (2d), 167, citing cases.

24 Hurt v. Drew (1927) - Kan. - 252 Pac. 249.

25 Roach v. Caraffa (1890) 85 Cal. 436, 25 Pac. 22; Souza v. First National Bank (1918) 36 Cal. App. 384, 171 Pac. 1084.

26 Supra, n. 13. 
the remedy, and that the execution of a subsequent writing, disclosing the terms of the agreement, is sufficient to permit the maintenance of an action on it. ${ }^{27}$

This is upon the theory that the statute of frauds merely created a rule of evidence that such agreement could not be proved unless the essentials of it had been reduced to writing and signed by the party to be charged. ${ }^{28}$

The law of this state now seems to be settled that unless the making of the agreement is denied by the answer, or the absence of a memorandum is pleaded, or the objection is otherwise properly urged, it is waived. ${ }^{29}$

There would seem, however, to be no justification for regarding the statute of wills as merely declaring a rule of evidence as in the case of the statute of frauds. ${ }^{30}$

As the supreme court of California has held: "The right to make a testamentary disposition of one's property is purely of statutory creation, and is available only upon a compliance with the requirements of the statute. The formalities which the legislature has prescribed for the execution of a will are essential to its validity, and cannot be disregarded. The mode so prescribed is the measure for the exercise of the right, and the heir can be deprived of his inheritance only by a compliance with this mode." 31

It is true that when a will purports to bequeath or devise property to a person as trustee for the benefit of an un-named beneficiary, there is in one sense a compliance with the statute. But such compliance would appear to be but formal. The subject-matter of the trust is obviously intended for an unknown beneficiary, which the statute would not appear to sanction. Of course, if the intention to create a trust does not appear upon the face of the will, the situation is entirely different. ${ }^{32}$

It would therefore seem that, even conceding that a trust such as was involved in Curdy v. Berton would be valid if inter vivos,

27 Producers' Fruit Co. v. Goddard (1925) 75 Cal. App. 737, 243 Pac. 686; Kinney v. Jos. Herschspring \& Co. (1921) 53 Cal. App. 628, 636, 200 Pac. 737; In re Balfour \& Garrette (1910) 14 Cal. App. 261, 111 Pac. 615. 28 Harper v. Goldschmidt (1909) 156 Cal. 245, 104 Pac. 451.

29 Gard v. Ramos (1913) 23 Cal. App. 303, 138 Pac. 108; cf. 2 California L. Rev. 153 (1914).

so It is true that the statute of wills was supplemented at a later date by the statute of frauds, which also contained a provision dealing with the form of wills of land. However, in modern usage, the term "Statute of Frauds" is generally used as referring to other sections of that statute than the one dealing with wills.

31 Estate of Seaman (1905) 146 Cal. 455, 459, 80 Pac. 700.

32 O'Donnell v. Murphy (1911) 17 Cal. App. 625, 120 Pac. 1076. 
the same ruling may not be made where, as in that case, the attempted trust is testamentary in character.

But still another possible solution presents itself.

It has long been settled in most jurisdictions in this country that when property is given by will or deed, "on trust," but no beneficiary is named, the grantee or devisee holds under a resulting trust. ${ }^{33}$

It is true that in Estate of Pichoir ${ }^{34}$ it was held, in accordance with the rule laid down in Estate of Fair, ${ }^{35}$ that when a will purports to leave real property in trust for a purpose not authorized by section 857 of the Civil Code, no title vests in the trustee and the heirs of the testator take the property, as undisposed of by the will..$^{30}$ But, as has been suggested, such a holding is in effect to declare the will void. "The will takes effect, the trustee gets the legal title, but must hold it for the benefit of the heirs or next of kin" under a resulting trust. ${ }^{37}$ Moreover, in Lauricella v. Lauricella, ${ }^{88}$ it was held that section 857 of the Civil Code has no application to trusts created by operation of law.

Although, as stated above, it is generally held that under such circumstances the trust is for the heirs of the grantor or testator, it may be questioned whether this result necessarily follows. Particularly is this true when we consider the phraseology of certain sections of our Civil Code, viewed in the light of their legislative history.

It was held in New York, prior to the Field draft of the Civil Code, that when a person advances the purchase price for certain property, the title of which is taken in the name of another as grantee, under an oral understanding with him that the grantee is to hold for the benefit of a third person, the latter may enforce the trust. ${ }^{80}$

As the Supreme Court said in that case:

"The payment of purchase money is uniformly sufficient to take a verbal agreement to convey or create any estate in lands out of the statute, where it would be a fraud and hardship upon the party unless the agreement were executed. (See Malins v. Brown, 4 Const. 403.)

"Nor does it weaken the case, or expose it in any greater degree to the prohibitions of the statute of frauds, that the payment of the money by or for the cestui que trust, and the

383 Pomeroy, Equity Jurisprudence, 4 ed., $\S 1032$ (1918). This section of Mr. Pomeroy's treatise is quoted in Wittfield v. Forster (1899) 124 Cal. 418, 57 Pac. 219. Also see Bogert on Trusts, 98 (1921).

84 (1903) 139 Cal. 682, 73 Pac. 606.

35 (1901) 132 Cal. 523, 64 Pac. 1000.

36 A.ccord, Estate of Sanford (1902) 136 Cal. 97, 68 Pac. 494.

37 Bogert on Trusts, 99 (1921).

38 (1911) 161 Cal. 61, 118 Pac. 430.

${ }^{30}$ Sieman v. Austin (1864) 33 Barb. 9, aff'd. 29 N. Y. 598. 
contemporaneous conveyance to the trustee, were accompanied by a verbal agreement on the part of the trustee, that he would hold and convey the property for a third person in accordance with the intention of the parties. The law will not indeed permit a trust to be declared or created by a mere verbal declaration of this intention, or a verbal agreement to do any act in the future. But where a state of facts is proved which establishes an equity independent of any agreement, evidence of such an agreement, although altogether verbal, does but define and determine the equity." 40

In other words, the trust is not created by parol, but by the circumstances of the case, and the function of a court of equity is merely to determine who is the proper person to benefit by the trust. It should be borne in mind that both resulting and constructive trusts are the creation of courts of equity, and that the beneficiary of such trusts is the person whom equity deems the proper person to benefit by them.

When the Field draft of the Civil Code was formulated, the Code Commissioners who had charge of its preparation so worded the provision of the Code dealing with the subject under consideration as to avoid, ex industria, the effect of that decision. Section 281 as it was drafted, and as it was originally adopted in this state, read as follows:

"Where a transfer of real property is made to one person, and the consideration therefor is paid by or for another, no use or trust results in favor of the person by or for whom such payment is made, but the title vests in the grantee, subject only to the provisions of the next two sections."

The New York Code Commissioners in their note to the section stated that "the words 'or for' are intended to supersede the doctrine of Sieman v. Austin, a decision which leaves much room for the frauds which this section was meant to avoid."

However, the section as originally drafted, and adopted in this form in California, prohibiting as it did a well recognized type of resulting trusts, did not meet with approval in this state. Almost immediately after its enactment, it was amended so as to read:

"When a transfer of real property is made to one person, and the consideration therefor is paid by or for another, a trust

40 Emmons v. Moore (1877) 85 Ill. 304; Freeland v. Williamson (1909) 220 Mo. 217, 119 S. W. 560; Gilbert v. Gilbert (1864) 2 Abb. Dec. 256, 40 N. Y. (1 Keyes) 159; Peiffer v. Lytle (1868) $58 \mathrm{~Pa}$. St. 386; Hardman v. Orr (1871) 5 W. Va. 71.

Sieman v. Austin, supra, n. 39, was considered and disapproved in Randall $v$ Constans (1885) 33 Minn. 329, 23 N. W. 530 . Also see the article by Professor Scott, 40 Harvard L. Rev. 669, 691-2 (1927).

41 Supra, n. 39. 
is presumed to result in favor of the person by or for whom stch payment is made." 22

The intention of the legislature is therefore clear that when a court of equity finds that the circumstances are such as to justify a decree that a resulting trust of the kind treated in the code section quoted above exists, such decree should run in favor of the beneficiary intended by the settlor.

A similar legislative intent appears in the case of constructive trusts. Section 2224 of the Civil Code provides that:

"One who gains a thing by fraud, accident, mistake, undue influence, the violation of a trust, or other wrongful act, is, unless he has some other and better right thereto, an involuntary trustee of the thing gained, for the benefit of the person who would otherwise have had it."

Since both in the case of resulting trusts embraced within section 8.53 of the Civil Code, and in the case of constructive trusts embraced by section 2224, the legislature has expressed its intent that the beneficiary intended by the settlor should take the property, there would seem to be no insuperable reason why the intended beneficiary should not also take in such a case as was considered by the court in Curdy v. Berton. It is true that as stated above, in a few cases it has been held that when an attempted trust fails the grantor or devisor, or his heirs, shall take, ${ }^{48}$ and that parol evidence giving to a resulting trust an effect different froin that which the law would ordinarily declare, is inadmissible. 4 But these authorities do not necessarily govern in a state of facts such as appear in Curdy v. Berton.

Moreover, the Supreme Court of California has held ${ }^{45}$ that a decision rendered by it which is in conflict with the terms of a Code section to which its attention was not directed, is of no validity and should be ignored.

By the same reasoning, it would appear that decisions which have been rendered without consideration of the clear implication of certain Code sections, likewise should not be regarded as settling the law on the subject.

42 Cal. Civ. Code, $\S 853$. It should be borne in mind that notwithstanding the language of the code section, dealing as it does with real property alone, the California courts hold that the same principle applies when the subject of the trust is personal property. Thompson v. Bank of California (1906) 4 Cal. App. 660, 667, 88 Pac. 987. n. 33 .

48 Estate of Pichoir, supra, n. 34; also see Wittield v. Forster, supra,

*t Breitenbucher v. Oppenheim (1911) $160 \mathrm{Cal}$. 98, 102, 88 Pac. 987, dictum.

${ }^{45}$ Alferitz v. Borgwaldt (1899) 126 Cal. 201, 58 Pac. 460. 
The line of reasoning set out above permits an adherence to the ultimate holding in Curdy v. Berton, although on the radically different ground that the beneficiaries named by the testatrix were entitled to take under a resulting trust in their favor. That the disposition made of that case apart from the reasoning pursued by the court has met with approval, notwithstanding the discordant decisions on various allied subjects, is indicated by its subsequent citation on various occasions. ${ }^{46}$

Robert L. McWilliams.

San Francisco, California.

16 Brazil v. Silva (1919) $181 \mathrm{Cal} .490,497,185$ Pac. 174; Estate of Lyon (1912) 163 Cal. 803, 805, 127 Pac. 75; Estate of Everts (1912) 163 Cal. 449, 454, 125 Pac. 1058. 